\title{
WORK-LIFE BALANCE: A COMPARITIVE ANALYSIS OF PERCEPTIONS OF EMPLOYEES WORKING IN PUBLIC AND PRIVATE SECTOR BANKS IN MYSURU CITY
}

\section{Dr. Āshwini S*}

\section{Siddaraju S}

\section{ABSTRACT}

\section{ABSTRACT}

Services play a central role in the economies of both developed and developing countries. They account for nearly half of the gross domestic product of all developed economies and constitute single largest sector in most developing economies like India. Work-life balance is a concept of having proper prioritizing between "work" and "lifestyle". Both of these are inseparable and form a source of conflict. The aim of this study is to find out the employee's perception regarding their work life balance, between public and private sector banks in Mysuru. WLB factors such as working environmental variables, leave policy variables and WLB Programme variables were being considered. Exploratory research method is employed. Simple Random sampling method is followed. Survey was conducted and data was analyzed on the basis of responses provided by 90 ( 48 respondents from public sector banks and 42 from private sector banks) respondents. Data was analyzed with the help of descriptive statistics, mean, $t$-test and Anova. The findings of the study revealed that there is a no significant relationship between demographic factors such as designation, age, gender and experience and WLB factors of employees working in public and private sector banks. The study has suggested that if there is implementation of work life balance programmes in their banks, employees would be self-motivated and their commitment towards the organization shall increase.

\section{KEYWORDS : WLB, Leave Policy, Working Environment, Worklife Balance Programme, $t$ test}

INTRODUCTION:

Services play a central role in the economies of both developed and developing countries. They account for nearly half of the gross domestic product of all developed economies and constitute single largest sector in most developing economies. The service sector comprises Trade, Hotels and Restaurants, Transport, Communication, Banking, Insurance, Education and Research etc.. The main reason behind the tremendous growth of service sector is due to rapid urbanization, expansion of public sector and easy accessibility to efficient services. The successful growth of the primary and secondary activities in the economy, to a large extent is dependent on services offered by banking, insurance, trade, commerce, and numerous other services categorized as tertiary activities. For service sector human resource play a vital role in achieving organizational objectives by providing valuable services to the customers.

Work life balance is also known as work interference with the family and family interference with work. Work life balance means proper balance of employee's personal life with that of their professional life. Every employee tries to maintain the equilibrium between family, personal affairs and professional growth and advancement. If any one of these two are not favourable or not supportive to another then the employees will never find job satisfaction.

The efficiency of employee is dependent on job satisfaction and in turn it depends on work life balance. When employees are not mentally free, then the efficiency, commitment and participation in accomplishment of organizational goals are questionable. The productivity and profitability of an organization depends on two factors that are interconnected performance and commitment. Both these factors are again influenced by how employees are satisfied with the working environment and how they could balance their personal life without compromising with work. If the organization wishes to have efficient and enthusiastic employees, then they have to build sound policies which would reduce work life conflict and enhance performance, retention and reduced absenteeism.

This study is an attempt to explore the perceptions of employees working in public and private sector banks in Mysuru city related to work life balance factors. To analyze the research objectives, following map was constructed and the variables are generated from past research papers. The factors demonstrates the hypothetical association among work life balance and WLB factors.

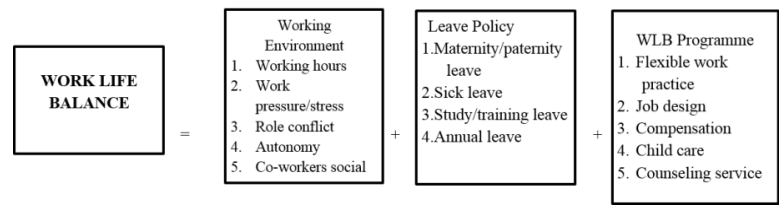

\section{REVIEW OF LITERATURE:}

- Adikaram et al., (2016), emphasized on work life balance with respect to Working hours, Working Conditions, Work Life Balance programs, Employee intention to change of job and work pressure. The study suggested that the work life balance has a significant impact on employee job satisfaction in private sector commercial banks of Sri Lanka.

- Obiageli et al., (2015), discovered that there is a significant positive relationship between leave policy and service delivery. The findings revealed that leave policy motivate employee ability to deliver services efficiently and effectively.

- Jani \& Virani (2019), examined the work environmental factors causing stress among working women in major five public and five private sector banks. The result of the study shows that work environmental factors have a significant relation with working women stress. The job stressors affecting the banking sector included overload of work, role conflict, role ambiguity, performance pressure, and job security and the other factors like working condition, lack of superior support and technological problem.

- Malik (2015), investigated the impact of work-life balance on marital status and gender of the people working in different companies in Delhi and NCR. A survey was conducted with a sample size $(\mathrm{N}=70)$ consisted of the first line management. The result shows that there was a significant relationship exists between work life balance and marital status. The gender had a marginal impact on WLB. The interaction effect of gender and marital status was also found significant.

\section{OBJECTIVES:}

1.To identify the factors that affect WLB of the employees 
working in public and private sector banks in Mysuru.

2. To know the relationship of demographic factors and WLB factors for employees working in public and private sector banks in Mysuru.

\section{RESEARCH HYPOTHESES}

$\mathrm{HO}$ - There is no significant relationship between demographic factors and WLB factors of employees working in public and private sector banks in Mysuru.

$\mathrm{Hl}$ - There is a significant relationship between demographic factors and WLB factors of employees working in public and private sector banks in Mysuru.

Reliability Statistics

\begin{tabular}{|l|l|}
\hline Cronbach's Alpha & N of Items \\
\hline .826 & 30 \\
\hline
\end{tabular}

RESEARCH METHODOLOGY:

Exploratory research method has been employed. Required data has been gathered from secondary sources of research articles and primary data has been collected with the help of structured questionnaire. The reliability test value of the questionnaire is $0.826>0.8$, it can be comprehended that the statements are reliable to test the hypothesis. The study is done with the help of Simple Random Sampling method, the questionnaires were distributed through Google form, selfadministered, the responses considered were 90 in numbers (48 respondents out of 119 branches of public sector and 42 respondents out of 30 branches of private sector). Statistical tests that were used for the study were mean, standard deviation, frequency, Independent sample t test and one way Anova.

\section{RESULTS AND DISCUSSION:}

Table No.1: Showing the Socio Demographic Details of Respondents

\begin{tabular}{|c|c|c|c|c|}
\hline \multicolumn{3}{|l|}{ Demographic Variables } & Frequency & Percentage \\
\hline \multirow[t]{7}{*}{ Bank Name } & \multirow[t]{3}{*}{ Private Sector Banks } & Karnataka Bank Ltd. & 20 & 22 \\
\hline & & ICICI Bank Ltd. & 15 & 17 \\
\hline & & HDFC Bank Ltd. & 13 & 15 \\
\hline & \multirow[t]{4}{*}{ Public Sector Banks } & State Bank of India & 17 & 19 \\
\hline & & Bank of Baroda (Vijaya Bank) & 13 & 14 \\
\hline & & Canara Bank & 12 & 13 \\
\hline & & Total & 90 & 100.0 \\
\hline \multirow{3}{*}{\multicolumn{2}{|c|}{ Designation }} & Manager Cadre & 34 & 38 \\
\hline & & Non-Manager Cadre & 56 & 62 \\
\hline & & Total & 90 & 100.0 \\
\hline \multirow{5}{*}{\multicolumn{2}{|c|}{ Educational Qualification }} & Post-Graduation & 51 & 57 \\
\hline & & Graduation & 28 & 31 \\
\hline & & PUC & 3 & 3 \\
\hline & & Other & 8 & 9 \\
\hline & & Total & 90 & 100.0 \\
\hline \multirow[t]{5}{*}{ Age } & & below 30 years & 38 & 42 \\
\hline & & $31-40$ years & 29 & 32 \\
\hline & & $41-50$ years & 13 & 15 \\
\hline & & above 50 years & 8 & 11 \\
\hline & & Total & 90 & 100.0 \\
\hline \multirow[t]{3}{*}{ Gender } & & Male & 60 & 67 \\
\hline & & Female & 30 & 33 \\
\hline & & Total & 90 & 100.0 \\
\hline \multirow[t]{3}{*}{ Marital Status } & & Single & 33 & 37 \\
\hline & & Married & 57 & 63 \\
\hline & & Total & 90 & 100.0 \\
\hline \multirow[t]{3}{*}{ Family Type } & & Nuclear Family & 61 & 68 \\
\hline & & Joint Family & 29 & 32 \\
\hline & & Total & 90 & 100.0 \\
\hline \multirow[t]{5}{*}{ Experience in Years } & & less than 5 years & 32 & 35 \\
\hline & & $5-10$ years & 26 & 29 \\
\hline & & $11-20$ years & 15 & 17 \\
\hline & & more than 20 years & 17 & 19 \\
\hline & & Total & 90 & 100.0 \\
\hline \multirow[t]{5}{*}{ Number of Dependents } & & $1-2$ & 52 & 58 \\
\hline & & $3-4$ & 34 & 38 \\
\hline & & 5 & 2 & 2 \\
\hline & & above 5 & 2 & 2 \\
\hline & & Total & 90 & 100.0 \\
\hline
\end{tabular}

Source: Primary

Table No.2: Showing The Significant Difference Between DESIGNATION AND WLB Independent Sample t Test

\begin{tabular}{|l|l|l|l|l|}
\hline & $\mathrm{t}$ & Sig. (2-tailed) & Mean & Std. Deviation \\
\hline Employees are having job security. & 1.917 & .049 & 1.7321 & .88402 \\
\cline { 2 - 5 } & & & 1.7941 & \\
\hline $\begin{array}{l}\text { Delay in the completion of work disturbs mental health of the } \\
\text { employees. }\end{array}$ & -1.986 & .040 & 2.2500 & 1.03133 \\
\hline Employees are getting fair compensation & & & 2.9118 & \\
\cline { 2 - 5 } & & & 2.158 & .034 \\
\hline $\begin{array}{l}\text { Bank Regularly organizes Holiday camps, Yoga and Meditation } \\
\text { classes to refresh its employees. }\end{array}$ & 3.216 & .002 & 3.1765 & \\
\cline { 2 - 5 } & & & 3.7286 & 1.05928 \\
\hline
\end{tabular}




\begin{tabular}{|c|c|c|c|c|}
\hline \multirow[t]{2}{*}{ Bank offers In-House Doctor facility. } & 2.199 & .030 & 3.2321 & 1.09530 \\
\hline & & & 4.0294 & \\
\hline \multirow[t]{2}{*}{ Bank provides crèche facility for children } & 3.216 & .002 & 3.3036 & 1.02549 \\
\hline & & & 3.6471 & \\
\hline \multirow{2}{*}{$\begin{array}{l}\text { Bank employees are having self-rostering system which enable } \\
\text { employees to schedule their work. }\end{array}$} & 2.021 & .046 & 3.1964 & .90292 \\
\hline & & & 3.8824 & \\
\hline Bank gives flexible working timings. & 3.010 & \begin{tabular}{|l|}
.003 \\
\end{tabular} & 3.8824 & 1.03447 \\
\hline
\end{tabular}

\section{Source: Primary}

According to the Table No. 2, it can be comprehended that there is no significant difference in the perception of employees working in public and private sector banks with respect to designation and following WLB factors.

The working environmental factors such as 'employees having job security' showed t value 1.917, p value $0.049<0.05$ and Std. deviation 0.88402, 'Delay in the completion of work disturbs mental health of the employees', showing t value 1.986, p value $0.040<0.05$ and Std. deviation 1 . The mean values however for private sectors stood at 1.73 and 2.25 and for public sector it stood at 1.79 and 2.91 respectively for the above two statements.

It can be comprehended that employees of public sector feel more secured regarding job than private sector employees, however disturbance of mental health due to delay in completion of work is more in public sector when compared to private sector employees.

WLB Programme factors such as 'Employees are getting fair compensation' showed t value 2.158 , p value $0.034<0.05$ and std. deviation .78438 while the statement 'Bank Regularly organizes Holiday camps, Yoga and Meditation classes to refresh its employees' showed t value 3.216 , p value $.002<0.05$ and std. deviation 1. The statement 'Bank offers In-House Doctor facility emphasized t value 2.199, p value $.030<0.05$ and std. deviation 1 and the factor 'Bank provides crèche facility for children tabulated t value - 3.216 , p value $.002<0.05$ and std. deviation 1. 'Bank employees are having selfrostering system which enable employees to schedule their work' shown t value at 2.021, p value $.046<0.05$ and std. deviation .90292. Regarding the factor 'Bank gives flexible working timings, $t$ value shows 3.010 while $p$ value is $.003<0.05$ and std. deviation resulted in 1 . The mean values however for private sector stood at $2.44,3.42,3.23,3.3,3.19$ and 3.88 and for public sector, it stood at 4.17, 3.79, 4.02, 3.64, $3.88,3.14$ respectively for the above six statements.

It can be inferred that public sector employees get fair compensation compared to that of private sector, public sector banks have been regularly organizing holiday camps, Yoga and meditation classes to refresh its employees which is less frequently organized by private sector banks, public sector bank employees are having in-house doctor facility, crèche facility for children compared to that of private sector banks employees, public sector banks employees are having more privilege of self-rostering system which provide them an opportunity of scheduling their work compared to that of private sector employees, however private sector employees are having more flexible working timings when compared it with the public sector employees.

Table No.3: Showing The Significant Difference Between MARITAL STATUS AND WLB

Independent Sample t Test

\begin{tabular}{|c|c|c|c|c|}
\hline & $t$ & Sig. (2-tailed) & Mean & Std. Deviation \\
\hline \multirow[t]{2}{*}{ Employees are having job security. } & 3.352 & .001 & 2.3333 & 1.31498 \\
\hline & & & 1.6316 & \\
\hline \multirow{2}{*}{$\begin{array}{l}\text { Bank provides an opportunity to its employees to fulfill their self- } \\
\text { esteem needs of growth and development. }\end{array}$} & 2.581 & .012 & 2.4545 & 1.06334 \\
\hline & & & 1.9474 & \\
\hline \multirow{2}{*}{$\begin{array}{l}\text { Employees are expected to work from home after normal working } \\
\text { hours. }\end{array}$} & -2.642 & .010 & 3.2727 & 1.17985 \\
\hline & & & 3.8947 & \\
\hline \multirow[t]{2}{*}{ Bank gives leave to care and support dependents. } & 2.168 & .033 & 2.6061 & 1.02894 \\
\hline & & & 2.1930 & \\
\hline \multirow[t]{2}{*}{ Annual leave helps employees to reduce work related stress. } & 2.351 & .021 & 2.4848 & 1.03444 \\
\hline & & & 2.0000 & \\
\hline \multirow[t]{2}{*}{ Leave policy enables employees to take care of their personal life. } & 3.031 & .003 & 2.2727 & .83937 \\
\hline & & & 1.8070 & \\
\hline \multirow[t]{2}{*}{ Employees get leave during the times of non-completion of work. } & -1.901 & .061 & 3.1515 & 1.03444 \\
\hline & & & 3.5439 & \\
\hline \multirow{2}{*}{ Bank provides counseling service to its employees. } & -2.203 & .030 & 3.0606 & 1.19738 \\
\hline & & & 3.5789 & \\
\hline \multirow[t]{2}{*}{ Bank provides Telecommuting facility. } & -2.032 & .045 & 2.3939 & .93339 \\
\hline & & & 2.8772 & \\
\hline
\end{tabular}

\section{Source: Primary}

It can be comprehended that there is no significant difference in the perception of employees working in public and private sector banks with respect to Marital status and WLB factors, according to the above table no. 3,

As revealed in the above table working environmental factors such as Employees are having job security, showing $t$ value 3.352, p value $.001<0.05$ and std. deviation 1 . Bank provides an opportunity to its employees to fulfill their self-esteem needs of growth and development, showing $t$ value $2.581, p$ value $.012<0.05$ and std. deviation 1 . Employees are expected to work from home after normal working hours, showing $t$ value -2.642 , p value $.010<0.05$ and std. deviation 1 . The mean values however for the private sector stood at 2.33, 2.45 and 3.27 and for public sector stood at 1.63, 1.95 and 3.89 respectively for the above three statements.

It can be observed that public sector employees are expected to work from home even after the normal working hours during end of the financial year compared to that of private sector employees, however private sector employees are provided with an opportunities to fulfill their self-esteem needs of growth and development and they feel more secured with respect to job that compared with that of public sector employees.

Leave policy factors such as 'Bank gives leave to care and 
support dependents' showed t value at 2.168, p value being $.033<0.05$ and std. deviation stood at 1 . The factor 'Annual leave helps employees to reduce work related stress', showed $t$ value at 2.351 , p value at $.021<0.05$ and std. deviation stood at 1. 'Leave policy enables employees to take care of their personal life' factor showed t value as 3.031, p value being $.003<0.05$ and std. deviation stood at .83937. The factor 'Employees get leave during the times of non-completion of work, showed t value-1.901, p value at $.061<0.05$ and std. deviation 1 . The mean values however for the private sector stood at 2.6, 2.48, 2.27 and 3.15 and for public sector it stood at $2.19,2.0,1.18$ and 3.54 respectively for the above four statements.

It can be concluded that public sector employees can get leave even in non-completion of work compared to private sector employees. However, private sector employees feel more comfortable in getting leave to care and support dependents and even to take care of their personal life than public sector employees and private sector employees are of an opinion that the leave policy enables them to reduce their work related stress when it is compared with public sector employees.

WLB programme factors such as 'Bank provides counseling service to its employees', showed t value at 2.203 , p value as $.030<0.05$ and std. deviation stood at 1 . Factor 'Bank provides Telecommuting facility', showed t value as 2.032 , p value at $.045<0.05$ and std. deviation revealed .93339 . The mean values for private sector stood at 3.06 and 2.39 and for public sector stood at 3.57 and 2.87 respectively for above two statements.

It can be contemplated that public sector employees are having sufficient counseling facility and Telecommuting facility compared with that of private sector employees.

Table No.4: Showing The Significant Difference Between AGE AND WLB ANOVA

\begin{tabular}{|c|c|c|c|c|c|}
\hline & & $F$ & Sig. & Mean & Std. Deviation \\
\hline \multirow[t]{3}{*}{ Employees are having job security. } & Between Groups & 2.735 & .034 & 1.31498 & .22891 \\
\hline & Within Groups & & & .67166 & \\
\hline & Total & & & & \\
\hline \multirow{3}{*}{$\begin{array}{l}\text { Job keeps employees away from their family } \\
\text { too much. }\end{array}$} & Between Groups & 2.434 & .053 & 1.10354 & .19210 \\
\hline & Within Groups & & & 1.19470 & \\
\hline & Total & & & & \\
\hline \multirow[t]{3}{*}{ Bank provides crèche facility for children. } & Between Groups & 4.116 & .004 & 1.13150 & .19697 \\
\hline & Within Groups & & & 1.04414 & \\
\hline & Total & & & & \\
\hline \multirow[t]{3}{*}{ Bank provides Telecommuting facility. } & Between Groups & 3.172 & .018 & .93339 & .16248 \\
\hline & Within Groups & & & 1.16604 & \\
\hline & Total & & & & \\
\hline
\end{tabular}

\section{Source: Primary}

According to the above table no. 4, it can be comprehended that there is no significant difference in the perception of employees working in public and private sector banks with respect to marital age and WLB factors.

As revealed in the above table 'working environmental factors such as Employees are having job security' is showing $f$ value as 2.735 , p value being $.034<0.05$ and std. deviation is 0.22891 . 'Job keeps employees away from their family too much' factor is showing $f$ value at 2.434 , p value as $.053<0.05$ and std. deviation stood at 0.19210. The mean values however for the private sector stood at 1.31 and 1.1 and for public sector it stood at 0.67 and 1.19 respectively for the above two statements.

It can be inferred that job keeps public sector employees away from their families due to transfer of job to remote places without giving proper facilities in there compared to the private sector. However private sectors employees are having more job security compare with public sector, because of more mergers have been taking place in public sector has created job loss to the employees.

WLB programme factors such as 'Bank provides crèche facility for children' has f value 4.116, p value $.004<0.05$ and std. deviation stood at 0.19697 and factor 'Bank provides Telecommuting facility', has f value 3.172 , p value states $.018<0.05$ and standard deviation is 0.16248 . The mean values however for the private sector stood at 1.12 and 0.93 and for public sector it stood at 1.04 and 1.16 respectively for the above two statements.

It can be contemplated that public sector employees are having more 'telecommuting facility' than private sector employees. However private sector banks provide crèche facility for children of its employees to enhance their work efficiency compared with that of public sector.

Table No.5: Showing The Significant Difference Between EXPERIENCE AND WLB ANOVA

\begin{tabular}{|c|c|c|c|c|c|}
\hline & & $\mathbf{F}$ & Sig. & Mean & Std. Deviation \\
\hline \multirow[t]{3}{*}{ Employees are having job security. } & Between Groups & 4.123 & .009 & 2.2188 & 1.00753 \\
\hline & Within Groups & & & 2.0000 & \\
\hline & Total & & & & \\
\hline \multirow{3}{*}{$\begin{array}{l}\text { Bank provides an opportunity to its employees to } \\
\text { fulfill their self-esteem needs of growth and } \\
\text { development. }\end{array}$} & Between Groups & 2.640 & .045 & 2.4375 & .91361 \\
\hline & Within Groups & & & 2.1538 & \\
\hline & Total & & & & \\
\hline \multirow{3}{*}{$\begin{array}{l}\text { Job keeps employees away from their family too } \\
\text { much. }\end{array}$} & Between Groups & 6.084 & .001 & 2.5938 & 1.10306 \\
\hline & Within Groups & & & 2.5000 & \\
\hline & Total & & & & \\
\hline \multirow[t]{3}{*}{ Bank gives leave to care and support dependents. } & Between Groups & 2.867 & .041 & 2.5312 & .94985 \\
\hline & Within Groups & & & 2.5385 & \\
\hline & Total & & & & \\
\hline \multirow{3}{*}{$\begin{array}{l}\text { Sick leave helps to take care of employees } \\
\text { emotional health }\end{array}$} & Between Groups & 2.735 & .049 & 2.0625 & .35355 \\
\hline & Within Groups & & & 2.5000 & \\
\hline & Total & & & & \\
\hline
\end{tabular}




\begin{tabular}{|c|c|c|c|c|c|}
\hline \multirow{3}{*}{$\begin{array}{l}\text { Annual leave helps employees to reduce work } \\
\text { related stress }\end{array}$} & Between Groups & 3.583 & .017 & 2.1250 & .79312 \\
\hline & Within Groups & & & 2.5769 & \\
\hline & Total & & & & \\
\hline \multirow[t]{3}{*}{ Bank provides creche facility for children } & Between Groups & 5.315 & .002 & 3.0625 & 1.16224 \\
\hline & Within Groups & & & 3.7308 & \\
\hline & Total & & & & \\
\hline \multirow[t]{3}{*}{ Bank gives flexible working timings. } & Between Groups & 3.185 & .028 & 3.1562 & 1.08090 \\
\hline & Within Groups & & & 3.3077 & \\
\hline & Total & & & & \\
\hline \multirow[t]{3}{*}{ Bank provides Telecommuting facility. } & Between Groups & 6.002 & .001 & 2.4688 & .91526 \\
\hline & Within Groups & & & 2.4615 & \\
\hline & Total & & & & \\
\hline
\end{tabular}

\section{Source: Primary}

According to the above table no. 5, it can be comprehended that there is no significant difference in the perception of employees working in public and private sector banks with respect to experience and WLB factors.

As revealed in the above table working environmental factors such as Employees are having job security, showing f value 4.123, p value $.009<0.05$ and std. deviation 1 . 'Bank provides an opportunity to its employees to fulfill their self-esteem needs of growth and development' factor showed $f$ value 2.640 , while p value is $.055<0.05$ and std. deviation .91361 . 'Job keeps employees away from their family too much' factor shows $f$ value 6.084 , p value $.001<0.05$ and std. deviation stood at 1 . 'Delay in the completion of work disturbs mental health of the employees', showed $f$ value at 1.778 , p value $.157<0.05$ and std. deviation is 1 . The mean values however for private sector stood at 2.21, 2.43, 2.59 and 2.03 and for the public sector it stood at $2.0,2.15,2.5$ and 1.84 respectively for the above four statements.

It can be inferred that private sector employees are having more job security and they are having an opportunity to fulfill their self-esteem needs of growth and development needs better than public sector employees but work pressure keeps their family away from them that compared with the public sector.

Leave policy factors such as 'Bank gives leave to care and support dependents' shows f value as $2.867, \mathrm{p}$ value being $.041<0.05$ and std. deviation is .94985 . Factor 'Sick leave helps to take care of employees emotional health', showed $f$ value 2.735 , p value. $049<0.05$ and std. deviation stood at .35355. 'Annual leave helps employees to reduce work related stress' statement, showed f value at 3.583 , p value stood at $.017<0.05$ and std. deviation is .79312 . The mean values however for private sector stood at 2.53, 2.06 and 2.12 and for the public sector stood at 2.53. $2.5,2.57$ respectively for the above three statements.

It can be inferred sick leave helps private sector employees to take care of their emotional health and banks give them leave to care and support their dependents when compared with public sector. However the annual leave policy of public sector reduces the employees work related stress compare to that of private sector.

WLB programme factors such as 'Bank provides crèche facility for children' showed f value 5.315, $p$ value being $.002<0.05$ and std. deviation is 1. Factor 'Bank gives flexible working timings', showed f value 3.185 , p value is $.028<0.05$ and std. deviation stood at 1 . Bank provides Telecommuting facility showing f value 6.002, p value $.001<0.05$ and std. deviation at .91526 . The mean values for private sector stood at 3.06, 3.15 and 2.46 for the public sector it stood at $3.73,3.3$ and 2.46 respectively for above three statements.

It can be inferred that public sector banks have been providing crèche facility for their employees' children, flexible working timings and telecommuting facility when it is compared with that of private sector banks.

\section{FINDINGS:}

1. Public sector employees feel more secured with their job compared to private sector employees with the mean values 1.64 and 2.10 respectively, t value 2.207 , p-value 0.03 showing significant difference between the two sectors.

2. Private sector employees have to work more than 8 hours a day and they need to complete the work after the working hours compared to public sector employees with the mean values i.e.,3.22 and 3.61 respectively, p value 0.174 showing no significant difference between the sector however also indicating that despite if the sectors there is huge workload.

3. Private sector employees are getting sufficient study or training leave to improve their personal growth compared with the public sector employees stating p value as 0.684 showing no significant difference between the sectors with mean values 2.60 and 2.50 respectively.

4. Public sector employees can take the leave during the time of non-completion of work, however private sector employees have more work stress with the $\mathrm{p}$ value as 0.113 showing no significant difference between the sector and the mean values stated 3.57 and 3.25 respectively.

5. 'Work is assigned according to the qualification and interest of the employees' statement showed no significant difference between the sector which is supported by the p value 0.15 .

6. Public sector employees are getting better compensation and other benefits than private sector employees with the mean values 2.14 and 2.12 respectively.

8. Public sector employees are provided with flexible working timings compared to private sector employees.3.52 and 3.33 respectively.

9. Provision of in-house doctor facility shown $\mathrm{p}$ value at $0.00<0.05$ depicting mean values as 3.87 and 2.95 for private and Public sector employees respectively. The above values revealed that there is a significant difference between the sectors for the said statement.

10.Work life balance of male employees and female employees supported by $p$ value $0.972>0.05$ showed that there is no significant difference between the gender and the Work life Balance Factors. Hence it can be inferred that irrespective of the Gender the issues concerned with Work life Balance are perceived and executed by both men and Women (Ex: Job keep away from their family too much, Employees are expected to work from home after normal working hours, employees can take time off or leave when their child is suffering from illness, Sick leave helps to take care of employees emotional health.)

11. There is no significant difference between work life 
balance and marital status as stated by p value $0.675>0.05$ inferring that despite of Marital Status the WorkLife Balance issues remains the same inturn pointing the hectic work-life in the current era.

\section{CONCLUSION:}

It can be concluded that all individuals have different requirements at different stages in their life and therefore the concept of work life assumes different meaning at each of these junctures. This research has provided insight into the problems faced by the employees working in private as well as public sector and their quality of life in relation to their work. Work life balance is a set of principles, which holds that people are the most important source in an organization as they are responsible and capable of making valuable contribution and thus they should be treated with dignity and respect. Work life balance polices have the potential to improve employee morale, job satisfaction, performance level and reduce absenteeism. Problems have to tackle at grass root level, It is necessary for organizations to have good HR practices and processes in place, especially for its employees to ensure that they enjoy good quality of life.

\section{REFERENCES:}

1. Dr. Orogbu Lilian Obiageli, Dr. Onyeizugbe Chinedu Uzochukwu \& Chukwuemeke Deborah Ngozi, (2015)"WORK LIFE BALANCE AND EMPLOYEE PERFORMANCE IN SELECTED COMMERCIAL BANKS IN LAGOS STATE", European Journal of Research and Reflection in Management Sciences Vol. 3 No. 4.

2. Dr. Jyotindra M. Jani \& Prof. Sanjita Virani(2019), AN ANALYTICAL STUDY OF STRESS AMONG WORKING WOMEN IN GUARAT (WITH SPECIAL REFERENCE TO BANKING SECTOR), PARIPEX - INDIAN JOURNAL OF RESEARCH, Volume-8,Issue-4.

3. D.S.R. Adikaram and Dr.Lakmini V.K. Jayatilake(2016), IMPACT OF WORK LIFE BALANCE ON EMPLOYEE JOB SATISFACTION IN PRIVATE SECTOR COMMERCIAL BANKS OF SRI LANKA, International Journal of Scientific Research and Innovative Technology, Vol. 3, No. 11.

4. Dr.Sangeetha malik (2015), EFFECT OF WORK-LIFE BALANCE ON GENDER AND MARITAL STATUS, International Journal of Science Technology and Management, vol.4, special issue no.l.

5. N Mohan, N Prabha, P. Mohanraj(2010), "Work Life Balance Through Flexi Work Arrangements: Emperical Study on Bank Employees". International Journal of Management(IJM), Vol. 1,PP 53-61.

6. Md. Mehedi Hasan, Sanuar Hossain(2018), "The Status of Work Life Balance for Women in Banking Sector and Its Impact on Their Perceive Performance in Bangladesh", IIARD International Journal of Economics and Business Management, Vol. 4 No. 72.

7. Sobia Shujat, Faroog-E-Azam Cheema, Faryal Bhutto(2011), "Impact of Work Life Balance on Employee Job Satisfaction in Private Banking Sector of Karachi", Journal of Management and Social Sciences Vol. 7, No. 2, 08-15.

8. Lalita Kumari (2012), "EMPLOYEES' PERCEPTION ON WORK LIFE BALANCE AND IT'S RELATION WITH JOB SATISFACTION IN INDIAN PUBLIC SECTOR BANKS", IJEMR , Vol 2 Issue 2

9. Vejandla Venkata Rama Krishnam Raju(2018), "Work Life Balance in Banking Sector - A Comparative Study of Public and Private Sector Banks", International Journal of Research in Management studies, Vol. no. 3, Issue no. 3.

10. V.Rama Devi, A.Nagini, "WORK-LIFE BALANCE AND BURNOUT AS PREDICTORS OF JOB SATISFACTION IN PRIVATE BANKING SECTOR", Skyline Business Journal, 9(1).

11. Rajesh K. Yadav, Nishant Dabhade(2013), "Work life balance amongst the working women in public sector banks - a case study of State Bank of India", International Letters of Social and Humanistic Sciences Online: 2013-09-26, Vol. 7, pp 1-22.

12. D. Manjula Sureshkumar. Dr. M. Selvakumar Marimuth(2014) "ANALYSIS OF QUALITY OF WORK LIFE OF EMPLOYEES IN PRIVATE SECTOR COMMERCIAL BANKS - APPLICATION OF DISCRIMINANT ANALYSIS", Abhinav National Monthly Refereed Journal of Research in Commerce \& Management, Volume 3, Issue 9.

13. Dr. Prabhat Kumar Singh, Kavita Salvi \& Sheetal Meena(2014), "GENDER DISCRIMINATION AND WORK LIFE BALANCE IN BANKING SECTOR", IRJMSH Vol 5 Issue 7.

14. Georgeta Panisoaraa, Mihaela Serbana(2012), "Marital Status and WorkLife Balance", Procedia - Social and Behavioral Sciences 78. 